\title{
アモルファス合金粉末の緩和，結晶化ならびに固化成形
}

\author{
井上明久社, 山本毅放, 増 本健斻 \\ 的 東北大学金属材料研究所, T980 仙台市青葉区.片平2-1-1. \\ 名2 新日本製鉄陎先端技術研究所, $\mathbf{T} 211$ 川崎市中原区井田1618.
}

\section{Relaxation, Crystallization and Consolidation of Amorphous Alloy Powders}

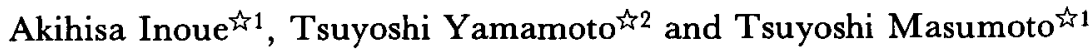 \\ s1 Institute for Materials Research, Tohoku University, Sendai 2-1-1 Katahira Aoba-ku 980 \\ it Advanced Materials \& Technology Research Laboratories, Nippon Steel Corporation, \\ 1618 Ida Nakahara-ku Kawasaki 211.
}

Received August 2, 1991

The influence of applied pressure on the structural relaxation, glass transition, crystallization and consolidation for an amorphous phase was examined by using a typical glassy $\mathrm{Pd}_{48} \mathrm{Ni}_{32} \mathrm{P}_{20}$ alloy in a spherical powder or a ribbon form. The Pd-Ni-P alloy was chosen because of the existence of a wide supercooled liquid region in the temperature range below crystallization temperature $\left(T_{x}\right)$. The relaxation and crystallization are significantly suppressed by the application of compressive load, presumably because of the increase in viscosity and the decrease in diffusivity. As a result, the pressing at a high temperature of $0.97 \mathrm{~T}$ is required to produce an amorphous bulk with high relative density. Furthermore, an intermediate annealing between pressings was found to be effective for the reduction of the enhanced viscosity. The multi-stage pressing treatment consisting of pressing and annealing enabled to produce a highly dense amorphous bulk even at a relatively low temperature near $\mathrm{T}_{\mathrm{g}}$.

\section{1 諸言}

アモルファス合金は、液体急冷法、気相㠜䑿法、固 相反応法、化学還元法などの方法により、薄带、細線、 粉末、薄膜などの形態として作製され、長範囲無秩序 充填構造と特異組成に起因する高強度、高勒性、軟磁 性、高酎食性などの特性と特殊な材料形態との組み合 わせにより、様々な分野において実用されている。と ころで、このアモルファス合金の応用分野をさらに应
大するためには、アモルファス材料の形状制限を出来 る限り除くことが重要である。このためには、より大 きなアモルファス形成能をもった合金組成を見出すこ と拉よびアモルファス粉末の固化成形法を確立するこ

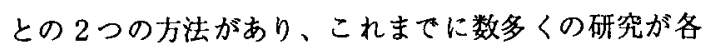
分野に扔いて行なわれてきている。ここでは、アモル ファス合金において秥晶化温度以下で広い過冷却液体 を示す合金のひとつである $\mathrm{Pd}_{48} \mathrm{Ni}_{32} \mathrm{P}_{20}$ を用いて、固 
化成形の最も基整的性質であるアモルファス粉末の楥 和と結晶化に及ほす加圧力の影響ならびに一軸圧縮㐫 カ下での固化成型挙動について概説する。

$2 \mathrm{Pd}_{48} \mathrm{Ni}_{32} \mathrm{P}_{20}$ アモルファス粉末とその固化成型法 Pd、Nifよび赤燐の各純粉末を生粉後焼結し、こ の焼結体を高周波溶解することにより $\mathrm{Pd}_{48} \mathrm{Ni}_{32} \mathrm{P}_{20}$ の 母合金を作製した。この母合金から、擋伴水中冷却法 1) 抢よび回転液中噴出法 2 ）を用いてほほ球形のア モルファス粉末を作製した。粉末粒径は、作製手法を 変えることにより74〜1190 $\mu \mathrm{m}$ の範囲で変化させるこ とができ、粉末を篩で分級後、実験に供した。バルク 状アモルファス合金の作製と圧力下における構造㗔和 およびガラス遷移挙動の研究には、一軸真空ホットプ

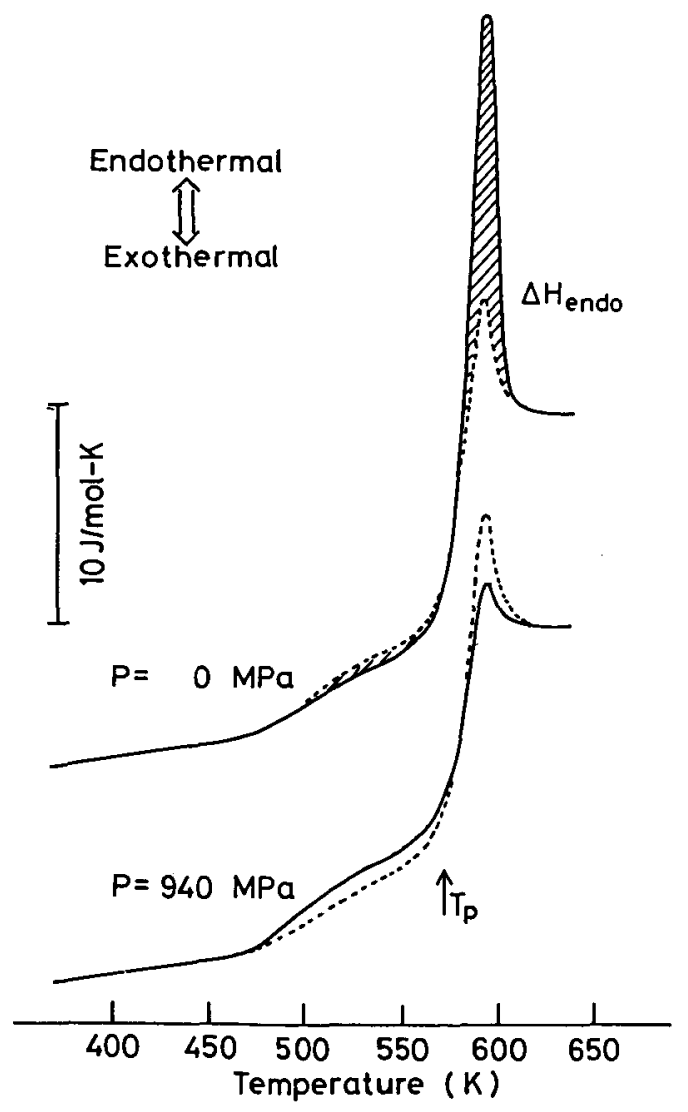

Fig. 1 Change in the relaxation-induced endothermic peak of an amorphous $\mathrm{Pd}_{48}{ }^{\mathrm{Ni}}{ }_{32} \mathrm{P}_{20}$ powder by pressing for $1.8 \mathrm{ks}$ at $573 \mathrm{~K}$. The dotted lines represent the data on the sample annealed for $60 \mathrm{~s}$ at $650 \mathrm{~K}$.
レス装置を使用した。加圧方式は片押し型であり、最 高压力940MPaまでの加压が可能である。ダイスとラ ムにはマルエージング鎆を用い、これらには圧粉体の 收縮量を測起して、加区に伴う密度の变化が評価でき るように作動トランス型のひずみ計が取り付けてある。

3 アモルファス粉末の楥和に及はす加圧力の影響

Fig.1は はd $_{48} \mathrm{Ni}_{32} \mathrm{P}_{20}$ アモルファス粉末を940MPaの 圧力で $573 \mathrm{~K} 、 1.8 \mathrm{ks}$ 間加圧した武料と圧力が零で $573 \mathrm{~K}$ に $1.8 \mathrm{ks}$ 間加熱した試料の比熱一温度曲線を示し ている。王力を鱼荷しない試料では、570〜610Kの 温度域で大きな吸熱ピークが出現している。一方、圧 力を負荷した試料ではTpより高温域でも吸熱ピーク は見られない。この吸熱ピークは、 $573 \mathrm{~K} て ゙ 1.8 \mathrm{ks}$ 間加 熱中にアモルファス相中に発生した緩和構造がさらに 高い温度への加熱によりエネルギーを吸収して消滅す る、いわゆる復元反応に起因すると考えられており 3 4)この考えはX線構造解析によっても確認されてい

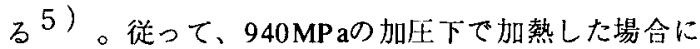
吸熱ピークが見られないことは、加圧により加熱中の 構造緩和がほほ完全に抑制されたことを示している。 またFig.2は573Kに1.8ks間焼なましたPdーNi-Pアモ ルファス合金の吸熱量（ $\triangle \mathrm{He} ）$ の負荷圧力による変 化を示している。 $\Delta$ Heは圧力の増加に伴いほほ值線 的に減少しており、加熱中の構造緩和は圧力負荷によ ク大きく抑制されるといえる。

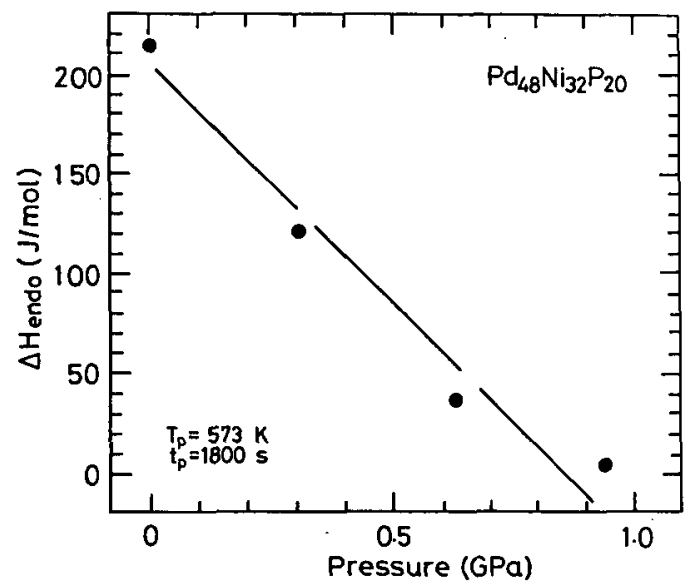

Fig. 2 The heat of relaxation-induced endothermic reaction ( $\Delta \mathrm{H}_{\text {endo }}$ ) as a function of applied pressure for an amorphous $\mathrm{Pd}_{48}{ }^{\mathrm{Ni}} 32 \mathrm{P}_{20}$ powder pressed for $1.8 \mathrm{ks}$ at $573 \mathrm{~K}$. 
Fig.3は無負荷および940MPaの加圧力下で $1.8 \mathrm{ks}$ 間 焼なましたPd-Ni-P合金の $\triangle \mathrm{He}$ の狫なまし温度依存 性を示している。無負荷および加圧状態ともに、 Heは温度の上界に伴い大きく增大し、ある温度（無 負荷では573K、加圧下では603K）でそれぞれ216J／ $\mathrm{mol} 、 169 \mathrm{~J} / \mathrm{mol}$ の最大值を示した後、さらに温度が 上昇すると急速に減少する。Fig.3に示すように $\triangle \mathrm{He}$ の最大値は加圧状態で䄪 $20 \%$ 低く、しかもその後の温 度上昇に伴う $\Delta \mathrm{He}$ の低下も小さくなっていることが 注目される。この結果は、加压がアモルファス固体か ら過冷却液体に僄移する温度を上昇させるのみならず、 過冷却液体における原子の内部平衡状態への再配列

（楥和）も抑制することを示している。Tgから過冷 却液体域での加压によるこの湿著な原子再配列の抑制 効果は、後で述べるように加压による粘性係数の増大 および粘性流動の大きな抑制をもたらしている。過冷 却液体域での原子移動は自由体積を介しての拡散によ りおこる6）が、加压下では自由体積が減少して、自 由体積を媒介とした搪散がおこりにくくなること、お よび原子自体の動きも加圧により抑制されるものと思 われる。このような加圧による原子移動度の減少がア モルファス固体から過冷却液体域での内部平衡状態へ の構造楥和の抑制をもたらしたものと考えることがで きる。

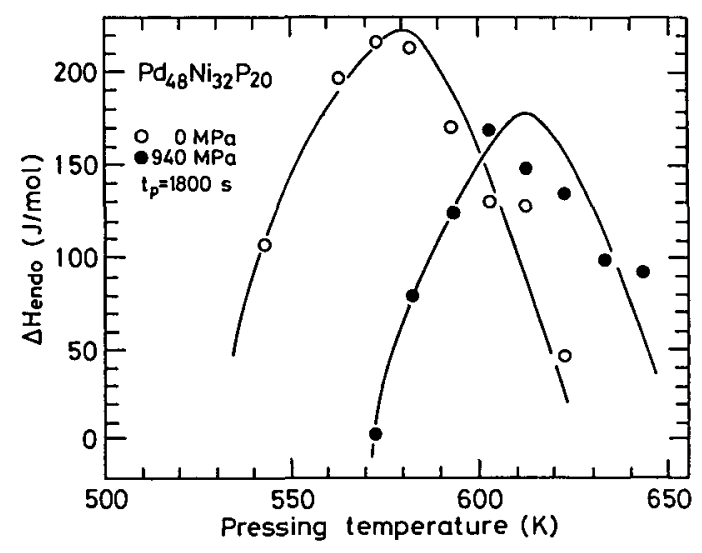

Fig. 3 The $\Delta H_{\text {endo }}$ as a function of pressing temperature $\left(\mathrm{T}_{\mathrm{p}}\right)$ for 1.8 ks for an amorphous $\mathrm{Pd}_{48} \mathrm{Ni}_{32} \mathrm{P}_{20}$ powder. The data of the unpressed powder are also shown.

\section{4 結晶化におよはす加压力の影響}

Fig.4はPd ${ }_{48} \mathrm{Ni}_{32} \mathrm{P}_{20}$ アモルファス薄帯の0.5、3.7およ び6.8GPaの圧少下での䉓気抵抗変化を示している。高 圧発生には六面体プレス機を使用し、試料澛度は压力 補正した熱起電力により測定した。図に示すように、 結晶化に伴う霍気抵抗の急激な減少が見られ、加压力 による結睧化の変化を正確に読みとることができる。 このようにして测定した $\mathrm{Pd}_{48} \mathrm{Ni}_{32} \mathrm{P}_{20}$ アモルファス合金 のTxは加底少の增大に伴いはほ值線的に上界し、その

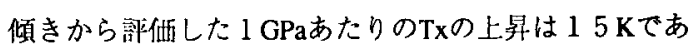

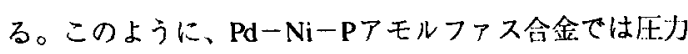
の負荷により、 $\mathrm{Tg}$ の上年や䧟冷却液体域の内部平衡状 態への䌅和の外に、Txを大きく上昇させて結晶化の開 始を困難にさせる。同様な加压力の増加に伴うTxの上 畀は、 $\mathrm{Pt}_{60} \mathrm{Ni}_{15} \mathrm{P}_{25} 7$ ) およびNi ${ }_{80} \mathrm{P}_{20} 7$ ) などの他の アモルファス合金においても譛められている。

\section{5 アモルファス合金粉末の固化成形}

$5-1$ 粘性係数の温度依存性

一-般にアモルファス合金はTgから $\mathrm{Tx}$ の温度域にお いて著しく軟化する。この軟化現象はアモルファス固

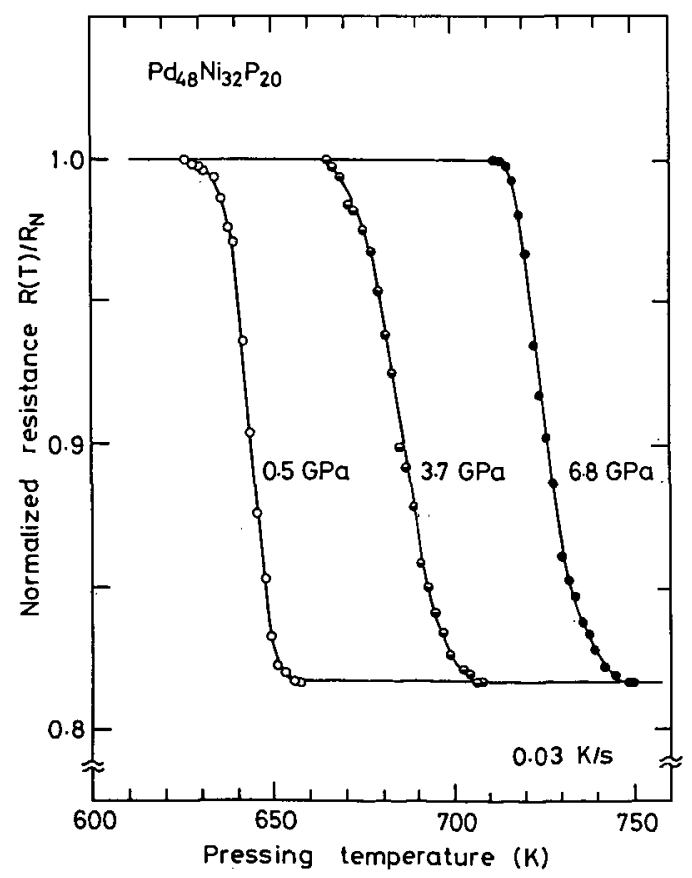

Fig. 4 Normalized electrical resistance as a function of $\mathrm{T}_{\mathrm{p}}$ for an amorphous $\mathrm{Pd}_{48} \mathrm{Ni}_{32} \mathrm{P}_{20}$ ribbon pressed at different applied pressures. 
体から過冷却液体へのガラス遷移によるためであり、 この結果アモルファス合金の変形梯式は不均一変形か ら均一な粘性変形に移行する。Fig. 5 は $\mathrm{Pd}_{48} \mathrm{Ni}_{32} \mathrm{P}_{20}$ アモルファス薄带の過冷却液体域での種々の応力下で の伸び挙動から求めた粘性係数（ $\eta ）$ の温度依存性を 示している。 $\eta$ は温度の上昇に伴い約 $10^{12} \mathrm{~Pa} \cdot \mathrm{s}$ から $10^{8} \mathrm{~Pa} \cdot \mathrm{s}$ に急激に隇少することがわかる。373Kで水 が飽和水蒸気に変化しても、クの变化率は高々 1 桁の オーダー（約1／23） 8）であることを考慮すると、 アモルファス合金がTgから $\mathrm{Tx}$ の狭い温度域できわか て急激に変形しやすくなるといえる。

\section{$5-2$ バルク状アモルファス合金の形成領域}

アモルファス合金のこの軟化現象に着目し、アモル ファス合金粉末を加圧変形することによりアモルファ ス相のままでバルク材を得ることが可能か否かを検討 した。このためには、ホットプレス時の年温条件 $(0.03 \mathrm{~K} / \mathrm{s})$ と同じ速度で加熱した場合の Tgと $\mathrm{Tx}$ を明 かにする必要がある。Fig.6はP ${ }_{48} \mathrm{Ni}_{32} \mathrm{P}_{20}$ アモルフ アス粉末の加熱に伴うDSC曲線を示している。この 図より、TgとTxはそれぞれ560K、620Kとなる。また、 Fig.5とFig.6に示すようにクはTgで10 $0^{12} \mathrm{~Pa} \cdot \mathrm{s} 、 \mathrm{Tx}$ $10^{8} \mathrm{~Pa} \cdot \mathrm{s}$ であり、 $\mathrm{Tg}$ から $\mathrm{Tx}$ への約 $60 \mathrm{~K}$ の過冷却液体域

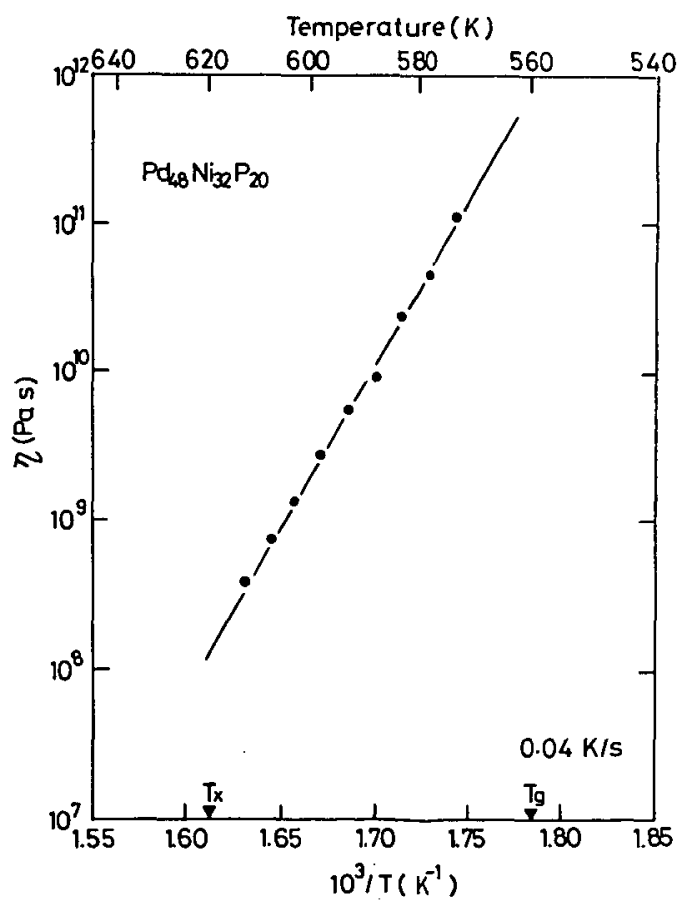

Fig. 5 Temperature dependence of viscosity $(n)$ for an amorphous $\mathrm{Pd}_{48} \mathrm{Ni}_{32}$ $\mathrm{P}_{20}$ ribbon.
において 4 析もの大きな変化をおこす。

$\eta$ の急激な減少に伴う粘性変形能の大きな增大を利 用して、アモルファス合金粉末から緻密度の高いアモ ルファスバルク材を成形するためには、高温で長時間 加圧した方が一般に有利と考えられる。ところが、ア モルファス合金をTx近傍で长時間加熱すると結晶相 に変態する。したがって、バルク状アモルファス合金 を作製するためには、適切な加圧時間と加圧力を選択 する必要がある。アモルファス合金の無加圧下での等 温変態時間図から、Tx近傍では短時間、 $\mathrm{Tg}$ 近傍では 辰時間の加庄により、アモルファスバルク材が得られ ると尒想される。しかしながら、意外にも実際のバル ク状アモルファス合金の形成域はこの予想と巽なり、 Fig.7に亦すようにTx近傍の600〜620K (0.97Tx〜TX) の温度範盲に限られ、加圧温度のみに強く依存するこ とが明らかになった。また、結晶化は $10.8 \mathrm{ks}$ の長時間 加压後においてもおこらないことが判明した。一例と して、Photo. 1 は $\mathrm{Tp}=613 \mathrm{~K} 、 \mathrm{tp}=3 \mathrm{~s} 、 \mathrm{P}=630 \mathrm{MPa}$ の加压: 焼結により得た $\mathrm{Pd}_{48} \mathrm{Ni}_{32} \mathrm{P}_{20}$ アモルファスバルク材の 断面の光学䫖微鏡組織を示している。3 s間の短時間 加圧によっても、粒界や粒界三重点に空渻は見られず、 真密度に近いバルク材が得られている。Feg.7に示し た温度域で得たバルク材の比密度は真密度の97.4 $99.2 \%$ 範用にあり、この値は Tpの上昇に伴い増大寸 るが、切あるいは加圧力が増大してもはとんど変化し ない。

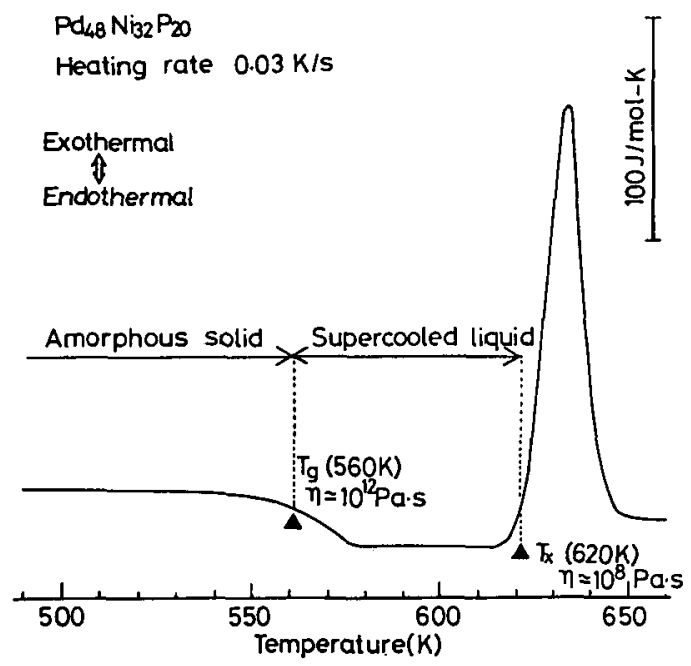

Fig. 6 Differential scanning calorimetric curve of an amorphous $\mathrm{Pd}_{48} \mathrm{Ni}_{32} \mathrm{P}_{20}$ ribbon. The data of $n$ are also shown for reference. 


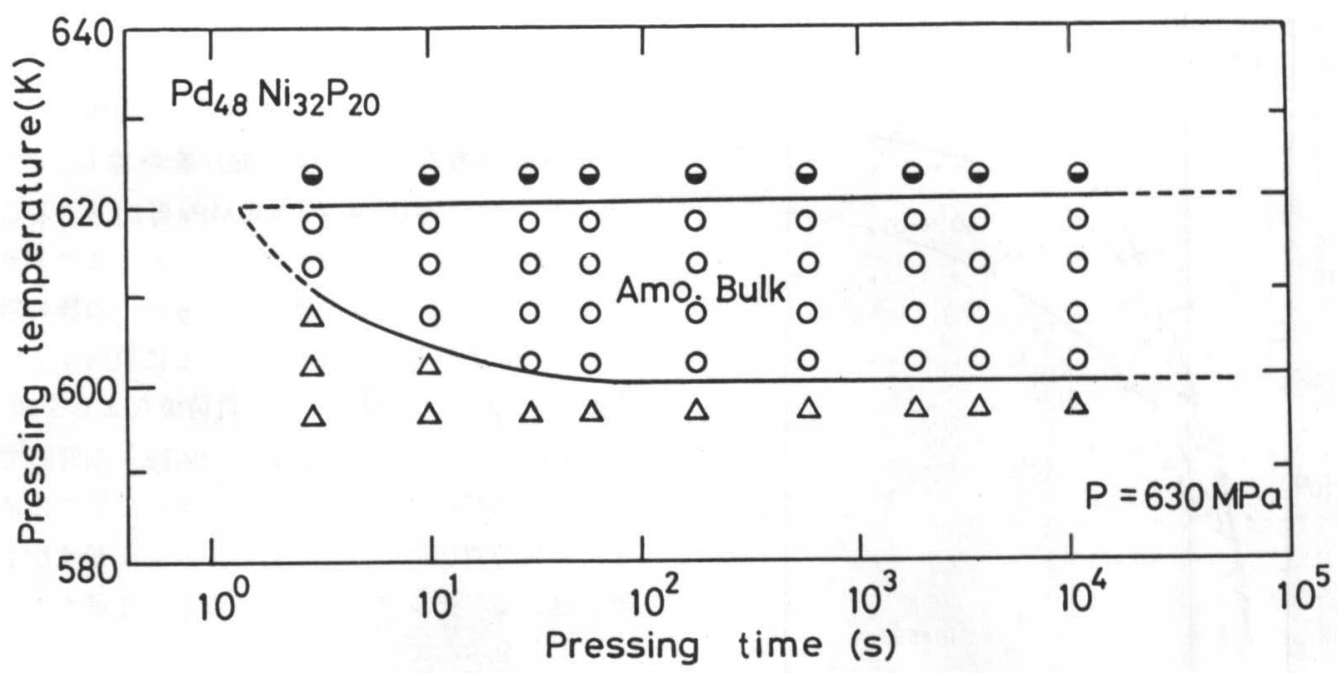

Fig. 7 Pressing temperature and time ranges for the formation of an amorphous bulk by pressing an amorphous $\mathrm{Pd}_{48} \mathrm{Ni}_{32} \mathrm{P}_{20}$ powder at $630 \mathrm{MPa}$.

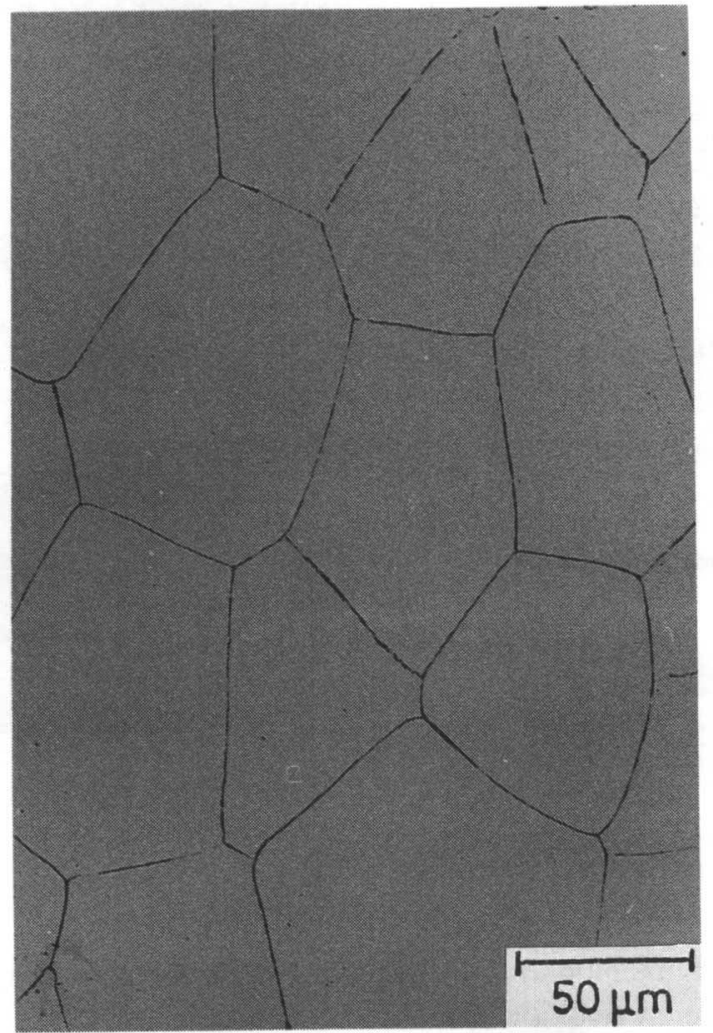

Photo. 1 Optical micrograph of an amorphous bulk produced by pressing an amorphous $\mathrm{Pd}_{48} \mathrm{Ni}_{32} \mathrm{P}_{20}$ powder under $630 \mathrm{MPa}$ for $3 \mathrm{~s}$ at $613 \mathrm{~K}$.
5-3 アモルファス合金の加圧下での変形様式

このようなアモルファス合金圧粉体の緻密化挙動を 検討するために、 化を調べた。その結果、過冷却液体域にある $\mathrm{Tp}=613 \mathrm{~K}$ での $\eta$ は、tpの増加に伴い急激に増大し、 $100 \mathrm{~s}$ 後には8.6× $10{ }^{8} \mathrm{~Pa} \cdot \mathrm{s}$ から約 $10{ }^{11} \mathrm{~Pa} \cdot \mathrm{s}$ になる。こ

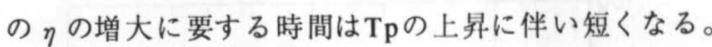
これは加圧に伴う原子移動時間が高温ほど短くなるた めと考えられる。また する。たとえば、Fig.8に示すように、Tp=593K、 $\mathrm{tp}=300 \mathrm{~s}$ での $\eta$ は、 $160 \mathrm{MPa}$ で $2 \times 10^{11} \mathrm{~Pa} \cdot \mathrm{s} 、 310 \mathrm{MPa}$ で $5 \times 10^{11} \mathrm{~Pa} \cdot \mathrm{s} 、 630 \mathrm{MPa}$ で $1 \times 10^{12} \mathrm{~Pa} \cdot \mathrm{s}$ であるこ のような加圧による $\eta$ の増大がFig.3に示したTgの上 昇をもたらすと結論できる。このような過冷却液体の $\eta$ の加圧力による大きな変化は、過冷却液体域で $\eta$ の 大きな低下を引き起こす原因である原子間の空陌（自 由体積）6）加加圧により隇少して、その結果加圧開 始より短時間のうちに粘性変形が難しくなると考えら れる。

\section{$5-4$ 多段加圧焼結}

前節において、加圧による ファス合金の特異構造に起因することを述べた。従つ て、加圧条件によりアモルファス合金の構造変化を制 御することができれば、クの増大を抑制でき、低温域 でもバルク材が作れることが期待できる。そこで $\mathrm{Pd}_{48} \mathrm{Ni}_{32} \mathrm{P}_{20}$ アモルファス粉末の加圧一焼なまし一加 圧の加工熱処理に伴う比密度の変化を調べた。Fig.9 


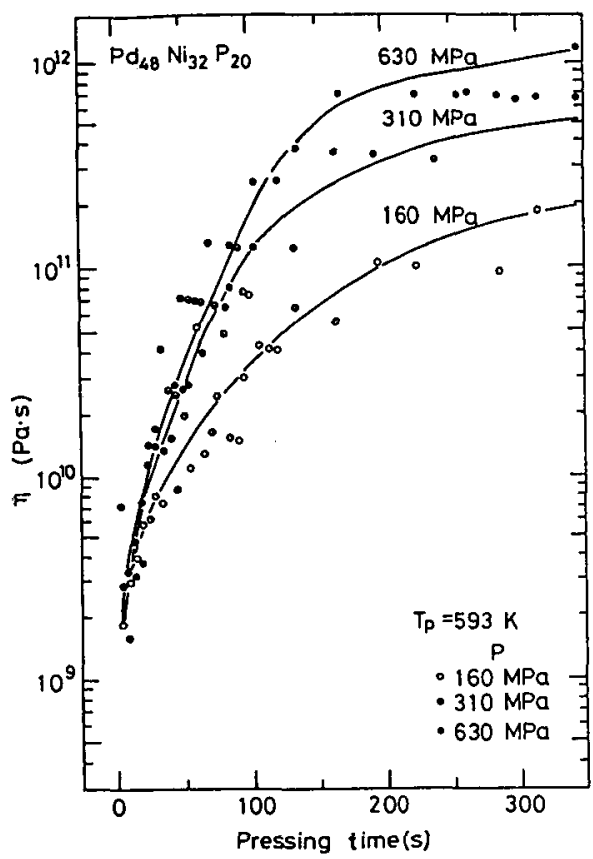

Fig. 8 Change in $n$ of an amorphous $\mathrm{Pd}_{48}$ $\mathrm{Ni}_{32} \mathrm{P}_{20}$ powder with pressing time at different applied pressures.

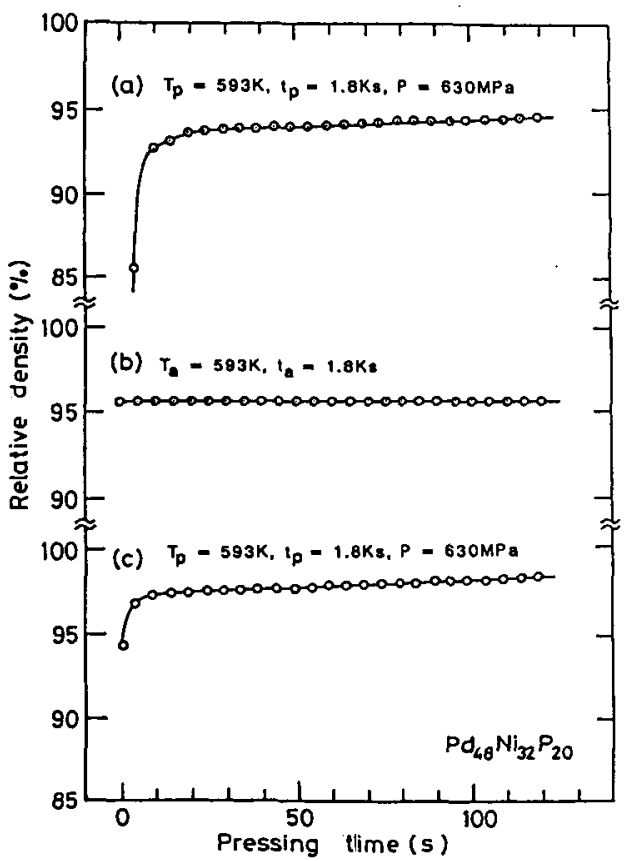

Fig. 9 Change in the relative density of an amorphous $\mathrm{Pd}_{48} \mathrm{Ni}_{32} \mathrm{P}_{20}$ powder by a multi-stage pressing treatment.
に示すように、與時間加圧してもバルク材が得られな かった593Kの低温度で加圧（630MPa）する時、加圧 開始後まもなく絊密化は停滞し、この段階での比密度 は96.5\%である。その後、加压を解除し、593Kで $1.8 \mathrm{ks}$ 保持後、再び593Kで630MPa再加圧することに より比密度は $98.2 \%$ に大く上昇する。このような多 段加圧効果は加圧により增大した $\eta$ がその後の無負荷 焼なましにより楥和、減少することに原因すると考え られる。加压（630MPa）と無負荷焼なましを60s毎に 100回繰り迈した結果、 $583 \mathrm{~K}(1.04 \mathrm{Tg})$ の低温でもア モルファスバルクの作製が可能であった。この結果は、 1 回の長時間加压に比べて短時間の加圧と焼なましの 繰り返しでアモルファス圧粉体の緻密化が大きく促進 することを示している。

\section{6 まとめ}

Tx以下の温度で広い過冷却液体域を示す典型的な ガラス状金属である $\mathrm{Pd}_{48}{ }^{\mathrm{Ni}}{ }_{32} \mathrm{P}_{20}$ を用いて、アモルフ アス合金の緩和と結晶化に及ほす加圧力の影響ならび にその影響と固化成型性との関連性を調べた結果を概 説した。その絬果、アモルファス合金の構造緩和と結 晶化は加圧才により大きく抑制されること、拉よびこ の抑制の結果比密度の高いアモルファスバルク材を得 るためには0.97Txのような滈温で成型しなければなら ないことを示した。さらに、Tg近傍の比較的低温域 においても、加圧により増大した粘性の低下をおこさ せる焼なまし処理を組み入れた多段加圧処理を施すこ とにより、高い緻密度をもったアモルファスバルク成 型体が得られることを明らかにした。

\section{文献}

1) A.Inoue, T.Ekimoto, H.M.Kimura, Y.Masumoto, T. Masum oto and N.Miyake : Met. Trans., $18 \mathrm{~A}$ (1987), 377.

2）大中逸雄、福迫達一、堤浩章：日本金属学会誌、 46(1982), 1095.

3 ) H.S.Chen : J.Non-Cryst.Sol ids, 46(1981), 289.

4) A. Inoue, T.Masu moto and H.S.Chen : J.Mater.S ci., 20、(1985)、2417.

5) Y.Waseda, E.Matsubara, M.Ohzora, A.P.Tsai, A. In oue and T.Mas umoto : J. Mater.Sci.Lett., 7(1988), 1003.

6) H.S.Chen : Rep. Prog. Phys., 43(1980), 353.

7 ) 山本 毅：東北大学修士学位論文、(1986).

8 ）化学便覽、基整編II、日本化学会編、(1984), P.41. 